\title{
Building E-Government 2.0 - A Step Forward in Bringing Government Closer to Citizens
}

\author{
Nataša Veljković, Sanja Bogdanović-Dinić and Leonid Stoimenov \\ University of Niš, Faculty of Electronic Engineering, Serbia
}

\begin{abstract}
This paper tracks the development of e-government towards the e-government 2.0 concept under the influence of WWW innovations and provides insight in how strategic goals of e-government 2.0 can be achieved in the Web 2.0 era. Although Western countries progress rapidly in achieving more open, participatory and transparent relations with users, by adoption of Web 2.0 technologies, less developed countries are slower to progress. This paper examines government websites in the developing countries of the Balkans for the presence of Web 2.0 applications and evaluates the results in comparison with more developed countries. It concludes with suggestions on how countries with e-government models prior to 2.0 can catch up and create an environment for citizen engagement and empowerment.
\end{abstract}

Keywords: e-government evolution, web 2.0, social media, government 2.0.

\section{Introduction}

The fast pace of technological innovations, Web 2.0 included, is causing major changes in ways people interact and converse with one another. Web 2.0 applications have provided new possibilities for user involvement and for this reason they gained popularity very quickly, especially among younger population. Sometimes referred to as the Net generation (Tapscott, 1998) or digital natives (Prensky, 2001), the young people of today use technology both for education and entertainment. Social networks, blogs and wikis are their playground. The virtual existence, embraced by the younger population is starting to permeate across all aspects of everyday life for all generations. This overall acceptance of Web 2.0 applications is affecting not only the way people communicate with one another, but also how they interact with thegovernment. They tend to participate, give suggestions, initiate changes and involve in egovernment services delivery. Governments can utilize the user driven nature of Web 2.0 in order to deliver value to the citizens (Ferro \& Molinari, 2009).

Web 2.0 applications can help governments to achieve the long-desired goals of government reform by making them more: simple and user-oriented, transparent and accountable, participative and inclusive, joined-up and networked (Osimo, 2008). Governments around the world are embracing new technologies in their everyday work, trying to keep up with modern trends and meet the public at most visited virtual places. With the rise of Web 2.0 set of technologies, governments gained an opportunity to provide transparency of information and greater functionality of citizen services. Web 2.0 has implied many changes not only in ways of communication between governments and users, but also in governmental concepts. A new participatory Web 2.0 platform provided a way for the transformation of governmental structures and public services. Governments are

Copyright (C) 2012 Nataša Veljković, Sanja Bogdanović-Dinić and Leonid Stoimenov. This is an open access article distributed under the Creative Commons Attribution License unported 3.0, which permits unrestricted use, distribution, and reproduction in any medium, provided that original work is properly cited. Contact author: Nataša Veljković E-mail: natasa.veljkovic@elfak.ni.ac.rs 
experimenting with new applications on the Web in order to achieve a more open and transparent relation with users. Public profiles on social networks, open forum discussions on hot topics and keeping blogs are just some of the actions that are being taken.

Changes in the organization of ecommunication have led to changes in core egovernment features and resulted in defining a new focus area and a new concept known as the e-government 2.0 concept. Egovernment 2.0 has emerged as a new term reflecting government transformation driven by the Web 2.0 impact. Web 2.0 applications and technologies offer opportunities for governments to provide better electronic services, improve communication with users and invoke active user participation in governmental work and activities. However, not all countries are able to adopt these technologies equally. Developed countries have shown much more initiative for this matter and much more comprehension of the importance and opportunities offered. They have invested in ICT infrastructure, legislation and education. E-government portals in such countries highly satisfy demands of e-government concept acting as a "one-stop-shop" for the citizens and offering them large number of online services. United Nations E-government 2010 Survey (UNPAN, 2010) has ranked world countries accordingly to the e-government development index and confirmed that highincome countries enjoy the top rankings. On the other hand, developing countries, such are countries of the Balkan region, struggling with economic, political and other challenges, have little time and resources to devote to egovernment development. They face a greater challenge considering investing in ICT infrastructure, policies and laws as well as human education. As a result egovernment in developing countries is almost always on a very low sophistication level compared to the e-government in developed countries. However, the consciousness and awareness of benefits of e-government is rising and increasing number of developing countries is working hard towards adopting and implementing these concepts. They are embracing new technologies, enacting laws and policies and investing in education and infrastructure.

In this paper we will present an analyzes on presence and utilization of Web 2.0 services and applications in developed and developing countries along with discussion on generated results. Prior we will explain the influence of Internet technologies in general on a development of e-government followed by detailed review of Web 2.0 technologies and their impact on governmental concepts. Final remarks and conclusions are given in the last section of the paper.

\section{Technology Driven Evolution of E- government}

Various factors drive e-government evolution - constant technological innovations, users' demands for better services, and need for enhanced collaboration inside and outside of government agencies. However, the innovations in information and communication technologies and the World Wide Web could be seen as the most influential factors, since they are considered as driving forces for quality and efficiency in public administration (Archmann \& Castillo Iglesias, 2010). Three models of egovernment can be identified and correlated with WWW evolution models (Table 1): egovernment 1.0, e-government 2.0 and egovernment 3.0. Characteristics listed in the table are applicable both for e-government and WWW evolution models. by listed Chinese companies," Journal of Accounting and Public Policy, 23, 191-225. 
Table 1: Evolution of the WWW and E-government

\begin{tabular}{|l|l|l|}
\hline \multicolumn{1}{|c|}{$\begin{array}{c}\text { World Wide Web } \\
\text { e-government 1.0 } \\
1989 \sim 2005\end{array}$} & \multicolumn{1}{c|}{$\begin{array}{c}\text { Web 2.0 } \\
\text { e-government 2.0 } \\
2005 \sim 2010\end{array}$} & $\begin{array}{c}\text { Web 3.0 } \\
\text { e-government 3.0 } \\
2010 \sim\end{array}$ \\
\hline Connecting computers & Connecting users & Connecting everything with everyone \\
\hline Supply based services & Demand based services & Intelligent agents \\
\hline Supplier generated content & User generated content & Machine generated content \\
\hline Read only & Read-write & Personal web \\
\hline One-way interaction & Two-way interaction & Live interaction \\
\hline Expert's intelligence & Collective intelligence & Artificial intelligence \\
\hline PC & PC, Mobile phone, PDA & Any device \\
\hline
\end{tabular}

The World Wide Web has been through various phases of development. It started merely as a toll to assists scientists at CERN but it grew to a global information space with more than a billion users (Anderson, 2007). With the emergence of the World Wide Web, in the early nineties, possibilities were opened for governments at all levels to reinvent their external operations and efficiency. Before the 1980s, governments were focused on improving internal efficiency and communication (Ho, 2002), but since the invention of the Internet, they were able to shift the focus to the external relationship with citizens and businesses. Initiative known as electronic government (e-government) was raised with aims to improve the way governments deliver services, engage constituents and perform overall governance. E-government was promoted as the use of information and communication technologies for enhanced access and delivery of government services to citizens, businesses and government employees (Silcock, 2001). It was expected from e-government to reveal the new form of governance and the willingness of government to implement the transformation of public-sector, internal and external relationships through internet enabled operations, internet technology and communications. As part of e-government initiatives and strategies, it was required from governments to do businesses online and offer their services over the Internet. They started to adopt this by creating websites, which at first played only an informative role.

Information on government structure, public announcements and contact information, however useful wasn't facilitating the completion of users' tasks with public administration. The presence of government organizations on the Web and the computeraided communication between them and the citizens was merely the beginning of egovernment introduction. Soon, government agencies and public bodies started creating and promoting online services for citizens and businesses, which were to reduce the administrative costs and the time needed for completing administrative procedures.

The idea of one stop shop of public services appeared as an alternative to functional departmentalization (Ho, 2002) and it was moved to the forefront of e-government initiatives. Serving citizens and businesses from a single point, twenty-four hours a day and in a user friendly manner became a foremost goal of every government. Eservices were delivered at citizens' doorstep, and the only thing expected from them was to open the door. However the expectations were different than the reality. Even though governments supplied services electronically, their consumption was low. In the European countries, for instance, where Internet is available to a broad population there was disproportion of e-services supply and consumption (Wauters et al., 2008). 
According to Eurostat's data, availability of eservices reached 58\% in 2007 (Eurostat, 2011). Still at the same time only $30 \%$ of Europeans were using the Internet for interaction with public authorities (Eurostat, 2011). Low consumption of e-government services was real concern for governments. One way to deal with this problem was to promote electronic services and talk about innovations in government.

Around the turn of the millennium, when new generation of technologies, applications and concepts appeared on the Internet under the name Web 2.0, it came apparent that they will change the prior way of communication between citizens and public sector. One stop shops, as a single window of e-service offerings, constitute one-way information channel with the citizens (Tapscott et al., 2008). Within the social media environment governments gained opportunity to transform citizens into public servants, offering them two-way channels for interaction, collaboration and information exchange with the-governments.

In contrast to Web 1.0 which was limited to users with high technical skills, Web 2.0 offered possibilities even for the less skilled individuals. Most of the Web 2.0 applications are free to use and do not require installation, meaning that anyone with a basic IT skills and any computing device (PC, mobile phone) can easily access them. Web 2.0 tools became pervasive in people's daily activities and it was expected from thegovernments to change their strategies and achieve more open relationship with their users. Enhancing the take-up of egovernment services among citizens became more certain goal with the rise of Web 2.0 applications and services. Usage statistics of social computing applications have been growing vertiginously since 2003 (Pascu, 2008). On the daily basis, more than 100.000 blogs are created, more than 1 million photos are updated and more than 40 million usercreated videos are uploaded (Pascu, 2008). Rapid adoption of Web 2.0 applications has instilled hope that there will be an increase in the use of e-government services, but for that to happen the concept of e-government had to change.

E-government 2.0 is more than "egovernment with a new name" (Collins, 2009, p.79). It's a fundamental shift in the implementation of government toward an open, collaborative and participatory model. E-government 2.0, as a technologically enhanced model of government, reflects government attempts to renew and modernize e-government and its relationship with public sector using Web 2.0 technologies. This assumes redesigning of government operations, back-office changes and more open engaging of governance which permits a plurality of stakeholders, intermediaries and channels in the service value chain (Millard, 2010). In e-government 2.0 technology blurs the roles of individuals, who are both information providers and information consumers, employees and citizens and the distinction between internal and external collaboration becomes artificial (Di Maio, 2009). This new model of egovernment was embraced not just in theory but also in practice. More than five years after the new governmental concept, known as government 2.0, started to appear in the literature (Eggers, 2005) it was adopted and confirmed in practice within governments all over the world. However, the e-government evolution does not end in this stage, it will continue under the new technological innovations and WWW development.

Today, more than twenty years from its deployment WWW strives to a new concept known as a Web 3.0. Web 3.0, a phrase coined by John Markoff (2006), is considered "the next frontier in Web technology which beholds the potential of intelligent information and semantic web" (Dwivedi et al., 2011, p.1). Nova Spivack considers Web 3.0 to be more than just "the intelligent Web" (2006). He defines Web 3.0 as a third generation of Web-based services driven by the convergence of several key emerging technology trends: ubiquitous connectivity, network computing, open technologies (open 
APIs and protocols, open data, open data formats), open identity (OpenID, open reputation, portable identity and personal data) and the intelligent Web (semantic web technologies, distributed databases, intelligent applications). Web 3.0, sais Nova, will be more connected, open, and intelligent, with semantic Web technologies, distributed databases, natural language processing, machine learning, machine reasoning, and autonomous agents. The past two decades have witnessed transitions of government model under the influence of Web 1.0 and Web 2.0 technologies. How will Web 3.0 affect the overall governance remains to be seen, but at least a fraction of the future can be anticipated from the following example. In 2009, U.S. government launched a web site Recovery.gov (www.recovery.gov) with intention to provide taxpayers with userfriendly tools to track how and where Recovery funds are spent. Recovery.gov is among the first U.S. government Web sites built on the Web 3.0 concepts (Government Computer News, 2010). Still in the not so distant future, governments around the world will advance toward e-government 3.0 model, a customized and intelligent government enabled by Web 3.0 technology.

\section{The Relevance of Web 2.0 for E- government}

Web 2.0 appeared as a consequence of various combinations of Web innovations over the last decade, including new technologies, applications and concepts (Murugesan, 2007; Osimo, 2008). Technologies associated with the new generation of Web, such as AJAX, XML, Flex, Microformats, allowed building applications for easy content creation and publishing. Blog, Wiki, Social networks, Virtual networks are just some examples of the Web 2.0 technologies legacy. Web 2.0 applications, otherwise known as social media (Kaplan \& Haenlein, 2010), bring new possibilities for user involvement in what makes up the Internet (Crook et al., 2008). They are all built on the same concept - user is the creator of content. This concept has opened infinite possibilities for users by allowing them to contribute to the Web as much as they consume it (Anderson, 2007). Formerly casted as the consumer, now as the creator of content, every user is able to make more meaningful contribution to the society.

Evidence of people's general acceptance and enthusiasm in using Web 2.0 technologies can be found in the following facts: during 2010 more than 13 million of hours of video were uploaded on YouTube (2010); every week more than 100 million of people likes, shares or comments on YouTube videos (YouTube, 2011); Wikipedia (2011) hosts more than 19 million articles written in 270 languages; Facebook (2011) has more than 750 million active users; nearly half million accounts are created daily on Twitter (2011); Twitter users post more than 140 million tweets per day which is one billion tweets per week (Twitter, 2001).

Usability of Web 2.0 applications witnesses their success and assures their existence. Soon after the acceptance by the civil society, the amplitude of Web 2.0 impact was spread further on the private and public sector. National and private universities, state institutions, private organizations and companies have engaged in the virtual world of Web that has given them possibility to serve users the same way as in the physical world:

- University of Deusto from Spain has developed a Second Life based remote laboratory which offers possibility for experiments (García-Zubia et al., 2010).

- Malta and Sweden have joined the Second Life virtual world, by creating embassies for their citizens (Zappen, Harrison \& Watson, 2008).

- $\quad$ The Dutch police officers have arrested a person on Habbo Hotel virtual platform for the theft of virtual furniture (de Kool \& van Wamelen, 2008). 
As in many other application domains, Web 2.0 has also merged into the e-government (Osimo, 2008; de Kool \& van Wamelen, 2008). Web 2.0 solutions can be used for the internal government operations such as cross-agency collaboration and knowledge management as well as for the soft issues as political participation and transparency, service provision and law enforcement (Osimo, 2008). Using Web 2.0 tools and applications, governments can improve and strengthen their communication with businesses and citizens, enhance internal cooperation and provide transparent, open and seamless services.

There are a number of Web-based applications that demonstrate the foundations of the Web 2.0 concept, and they are already being used to a certain extent in government:

- Social networks - web sites that allow users to connect and share information with one another (Timm \& Duven, 2008). Within a social network service each user has a virtual representation or profile through which he can interact with others. Tools for social interaction are not only limited to social networks (Facebook, LinkedIn), they also include social bookmarks (Delicious, Digg), virtual worlds (Second Life, OpenSim) and crowd-sourcing (IdeaScale, Chaordix). Social networks are used by people all over the globe, they are the place of their virtual existence. Governments can follow the example and create public profiles to interact with users and other parties interested in government business and services.

- Podcast - an audio content available on the Internet that can be automatically delivered to any computing device (Geoghengan \& Klass, 2005). Podcast is not necessarily limited to audio content, it can also include video files, text, pictures or other digital content. Podcast users subscribe to the RSS feeds and receive information about new podcasts as soon as they are available. With the delivery of digital content, such as recordings from meetings, speeches of government officials, explanations on votes, governments could increase transparency of governmental processes and raise the number of individuals participating in government (Meier \& Jakob-Brand, 2007).

- Wiki - a web site that allows visitors to create and edit web pages in collaboration with others (Chao, 2007). Wiki features easy editing and publishing of content which makes it extremely popular collaboration tool. Governments can use wiki as a knowledge exchange environment for their employees and users. Problems tend to repeat themselves, and a problem occurred in one-government, can be common in another. This is one more reason why exchange of knowledge between government institutions is important.

- Blog - personal website that allows the user to moderate its content, restrict access to content via user groups and control editing of posts. Blog can be used in isolation or integrated with other Web 2.0 tools. Government officials can use blog to express their views, report on their activities, chronicle their travels and give glimpses of their personal lives and interests.

- Micro-blog - a blog-like medium used for the exchange of content elements such as short sentences or links where individual posts could not exceed 140 characters. Micro-blog "stand halfway between traditional blogs and social networking sites" (Kaplan \& Haenlein, 2011, p.106). They are becoming an established category for news broadcast, even in the area of e-government. Many government officials over the world are using the most popular micro-blog, Twitter, to post important announcements to the audience. 
Millard (2010) casts an ambivalent question "Is the Bottle Half Full or Half Empty?" emphasizing that the-government adoption of Web 2.0 is somewhere in between egovernment 1.0 and e-government 2.0. Still as applications of e-government 2.0 spread throughout the world, it becomes more obvious that governments are stepping up with the private sector and the civil society in the usage of social media. Before Web 2.0, typical methods for sharing government information with the public included static Web sites, telephone information lines and printed publications. The problem with these methods was that information was often outdated. Web 2.0 brought possibilities for governments to publish information via dynamic Web portals keeping it current and up-to-date. Next generation of government Web portals are bringing people closer to government with more services, new designs and Web 2.0 social media capabilities. Being where citizens already are will allow governments to increase public engagement and evolve into more participatory governments.

Opportunities provided by Web 2.0 applications can lead governments to achieve the strategic objectives of e-government 2.0. These objectives have been recognized as (Baumgarten \& Chui, 2009; Government 2.0 taskforce, 2009):

- Openness and transparency

- Focus on user's demands and active user involvement (user participation)

- Collaboration of government agencies in data interchange

E-government 2.0 is a result of government using technology to put the citizens at the heart of things. It removes boundaries, promotes openness, transparency and user participation. Opening up the boundaries of the-government means inviting citizens, nongovernmental organizations and private enterprises to take their role in government, initiate new services, leave suggestions, and have access to governmental data that is of the essence in e-government 2.0. Information is no longer given "off the record" - open communication has prevailed.

Transparency in e-government is an idea which gained considerable momentum with the emergence of computing and Internet in general. More transparency means better governance, more efficiency and legitimacy. Government 2.0 involves a shift to a culture of openness and transparency, wheregovernment is prepared to engage and listen to its citizens and to make non-sensitive public sector information available for consumption (Government 2.0 taskforce, 2009). Web portals of governments around the world testify about the-government's willingness for removing the veil from the procedures and data and for opening up doors for the public:

- Data.gov is the U.S. government data portal. It reflects key e-government 2.0 and Web 2.0 principles, namely that data is at the heart of Internet applications. Data.gov community is very large and is constantly contributing to portal's growth by taking part in discussions, developing different kinds of applications for data analyses and data interlinking that helps generating more useful information from existing datasets.

- Another good example of a successful data portal is the U.K government's data portal (data.gov.uk). It offers a large number of data categories and it has large community that is involved in discussions and is encouraging portal's growth.

- The District of Columbia has also developed an excellent data portal (data.octo.dc.gov) that allows publishing, searching and downloading governmental data, available in reusable formats. 
- Web portal Grants.gov is the single access point for grant programs offered by U.S. federal grant-making agencies. It allows organizations to electronically find and apply for competitive grant opportunities.

User participation is another feature of egovernment 2.0 model. Users have the ability to report their satisfaction with egovernment services, comment on government work, and, moreover, have influence on future-government actions. Participation is about government asking people how to solve their problems, engaging them in policy-making and service delivery. In this way, more sophisticated, seamless, proactive and citizens-centred services can be offered. Examples of user participation in government are rapidly growing:

- Canada's FixMyStreet portal (www.fixmystreet.com) is designed to provide citizens information about their community by giving them the ability to browse, file new problems or subscribe to information on already reported problems in their neighbourhood.

- The U.S. Patent and Trademark Office's portal (patft.uspto.gov) shows an example of crowd-sourcing, by engaging citizens to provide input on the pending patent applications.

- Estonia's Web portal Today I Decide (tidplus.net) enables citizens to leave comments, vote on draft laws or present their own ideas for future laws.

Another pillar of e-government 2.0 is collaboration. Collaboration between governments and their users, citizens and businesses, help governments to provide better services and meet user demands. Aside from external collaboration between government and citizens, intra- and interinstitutional collaboration is important. This other dimension of collaboration involves exchange of documents, coordination of work, communication with third parties, decision making and knowledge management. Government 2.0 empowers citizens and public servants to collaborate in their own governance by harnessing the opportunities presented by Web 2.0 tools:

- GovLoop (www.govloop.com) is a social network for governments that contributes to knowledge exchange among government employees and professionals and serves as a platform for expertise, opinion and news network. Since its establishment in 2008 until today, GovLoop has grown to over 40000 users from all around the world.

- Intellipedia (www.intelink.gov) is a Web portal for collaborative data sharing between intelligence officials of the U.S. government.

Analysis of Social E-government: Presence and Utilization of Web 2.0 Services and Applications

Recent studies on the uptake of Web 2.0 tools in government (Queensland State Archives, 2010; CIO/OFT, 2010) testify that egovernment 2.0 is already adopted and implemented concept, especially within developed nations. Results of the studies indicate that over half of survey respondents, both in Queensland and New York State, are using Web 2.0 tools to enhance their business processes.

For the purposes of better understanding of the importance of Web 2.0 for e-government as well as the amount of usage of Web 2.0 tools, we have performed a research on presence and utilization of Web 2.0 services and applications within the countries of the Balkans and compared the results with the more developed governments in the Western World.

\section{Research Methodology}

The research involved two groups of countries. The first group includes countries with already highly developed e-government 
model. They were selected according to egovernment ranking from the United Nations E-government 2010 Survey (UNPAN, 2010). We will address them in the research as developed countries. Countries selected for the research, belonging to the developed countries group, are within the top 10 countries ranked by e-government development index: Republic of Korea, United States, Canada, United Kingdom, France and Singapore, with the exception of Singapore. Singapore is ranked 11 but it entered the study due to unexpectedly small number of countries within the top ten which utilize some of Web 2.0 tools and services. The second group of countries includes developing countries from the Balkan region: Serbia, Croatia, Slovenia, Montenegro, Bosnia and Herzegovina Federation, Bulgaria, Macedonia, Romania, Albania, Turkey and Greece.

The research was performed through completing the analysis of governments' utilisation of the following Web 2.0 tools: Facebook, Twitter, YouTube, Wiki, RSS, Blog, Podcast, Flickr and Scribd. These tools were selected accordingly to a research on Web 2.0 tools and applications presented in the third section of this paper and considering the main concepts of e-government 2.0 model. RSS, Podcast, Flickr, Scribd and YouTube are Web 2.0 tools that contribute to Openness and Transparency features of egovernment. Facebook, Blog and Twitter contribute to User Participation feature while Collaboration is added by Wiki. For both country groups several public authorities were analysed: the central government website and websites of public authorities linked from the-government website. The research has shown that developed countries have more public authorities that are exploiting some of the Web 2.0 tools than it is the case in developing countries. We have considered all public authorities we could find for the developing countries and approximately the same number of public authorities for the developed countries by randomly selecting public authorities available. The number of analyzed websites vary from eleven (Greece) to twenty-eight (France) and the most common ministries and agencies included are: Government, Statistical office, Department of labour, e-government portal, Ministry of interior, Ministry of finance, Ministry of education, Ministry of science, Ministry of technology, Ministry of foreign affairs, Ministry of justice, Ministry of health, Ministry of environment. The presence of each Web 2.0 tool was checked by examining the official website of an authority for a direct link towards the tool. If the link was found the tool was checked as used.

The countries used in the research are listed in Table 2, along with their corresponding egovernment development rank and the number of public authority websites analysed for each country. 
Table 2: Countries Selected for the Research

\begin{tabular}{|c|c|c|}
\hline & $\begin{array}{l}\text { E-government development rank } \\
\text { (UNPAN, 2010) }\end{array}$ & $\begin{array}{l}\text { Number of analysed } \\
\text { PA's websites }\end{array}$ \\
\hline \multicolumn{3}{|c|}{ Developed countries } \\
\hline Republic Korea & 1 & 12 \\
\hline United States & 2 & 12 \\
\hline Canada & 3 & 15 \\
\hline United Kingdom & 4 & 14 \\
\hline France & 10 & 28 \\
\hline Singapore & 11 & 18 \\
\hline \multicolumn{3}{|c|}{ Developing countries } \\
\hline Slovenia & 29 & 17 \\
\hline Croatia & 35 & 16 \\
\hline Greece & 41 & 11 \\
\hline Bulgaria & 44 & 13 \\
\hline Romania & 47 & 13 \\
\hline Macedonia & 52 & 14 \\
\hline Montenegro & 60 & 17 \\
\hline Turkey & 69 & 17 \\
\hline B\&H Federation & 74 & 14 \\
\hline Serbia & 81 & 18 \\
\hline Albania & 85 & 14 \\
\hline
\end{tabular}

\section{Research Results}

Web 2.0 tools are very present in governmental online work in all of developed countries listed in Table 2 - on average six tools per country (Figure 1A). Chart bars are mostly above $40 \%$ indicating a very good usage of Web 2.0 tools by more than a third of public authorities. 


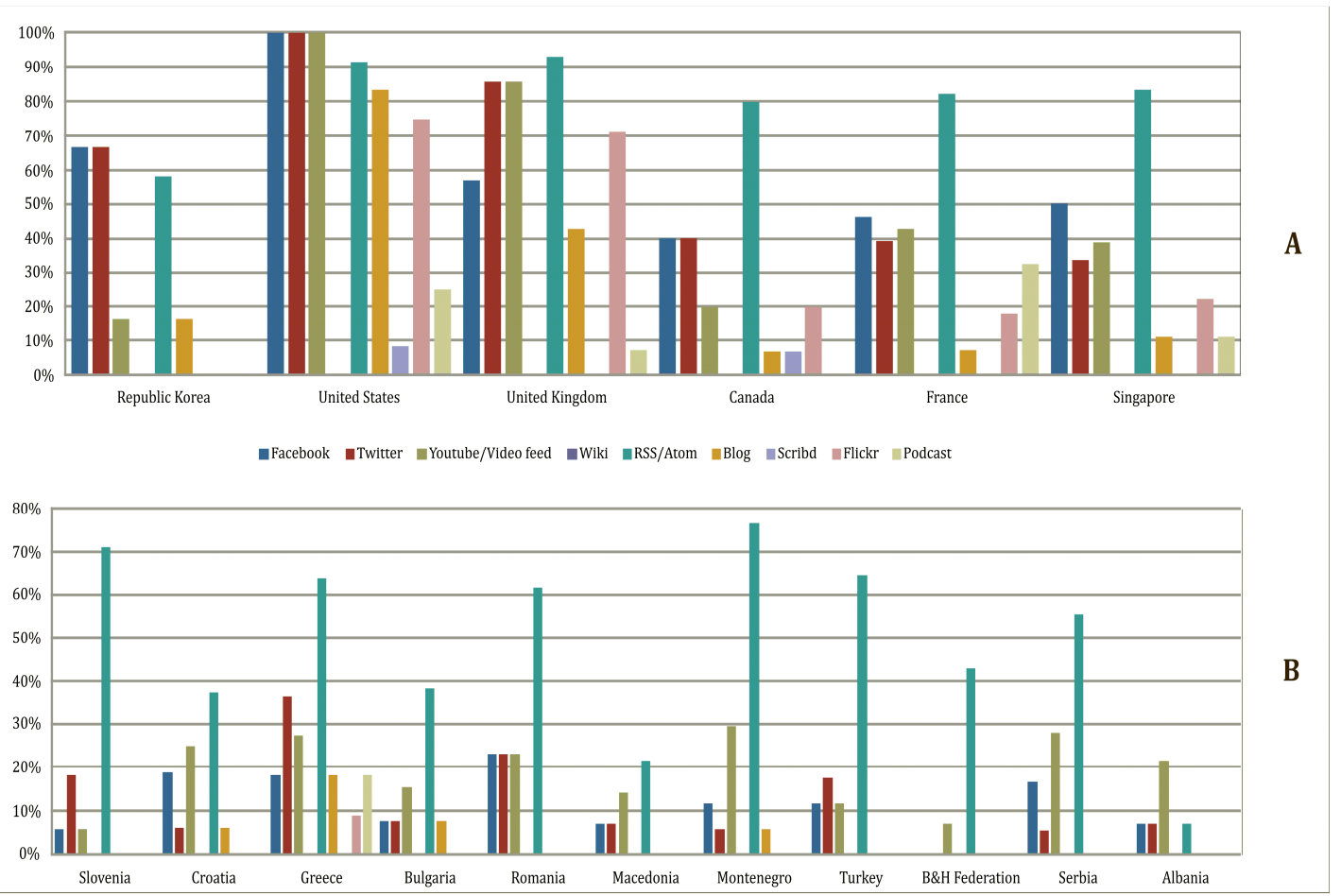

Fig1. Web 2.0 Tools Utilization

The situation in the Balkan region is considerably different (Figure 1B). The usage scale goes up to $75 \%$ opposite to developed countries that have scored $100 \%$. Chart bars are mostly below $25 \%$, indicating very low usage of analysed tools - on average four tools per country. The average number of Web 2.0 tools per public authority is one, which is considerably low, having in mind that the smaller group of highly developed countries has better average (three per public authority).

If we compare the Web 2.0 tools usage with the e-government development rankings, we can see that not necessarily higher ranked countries have higher usage percentage. Slovenia as the leading country in the Balkan group, according to the e-government development index, has deployed only four of analyzed social tools. B\&H Federation has higher e-government development index than Serbia, but Serbia has deployed twice as much Web 2.0 tools compared to B\&H Federation.

Table 3 shows average usage for each Web 2.0 tool both for the developed countries and for the countries of the Balkan region. In the developed countries, more than two thirds of analysed public authorities (81\%) support RSS based user subscription. This makes RSS the most used Web 2.0 tool in the survey. This result is not very surprising considering that RSS is one of the first Web 2.0 tools that has appeared. Tools like Scribd and Flickr are relatively new and still not exploited enough, thus low percentage on their usage is not very surprising. 
Table 3: Average Values of Web 2.0 Tools Utilization

\begin{tabular}{|l|c|c|}
\hline & Developed countries & Balkan region countries \\
\hline Facebook & $60 \%$ & $12 \%$ \\
\hline Twitter & $61 \%$ & $12 \%$ \\
\hline YouTube/Video feed & $51 \%$ & $19 \%$ \\
\hline Wiki & $0 \%$ & $0 \%$ \\
\hline RSS & $81 \%$ & $49 \%$ \\
\hline Blog & $28 \%$ & $3 \%$ \\
\hline Scribd & $3 \%$ & $0 \%$ \\
\hline Flickr & $34 \%$ & $1 \%$ \\
\hline Podcast & $13 \%$ & $2 \%$ \\
\hline
\end{tabular}

Average presence of Web 2.0 tools on the public authorities' websites for the countries of the Balkans is considerably lower. The most used Web 2.0 tool is RSS (49\%), while the least used ones are Wiki and Podcast (both with 0\%). These results indicate that Balkan region countries are still in development phase. They are just starting to take advantage of Web 2.0 tools in order to provide cost-effective way of communication with citizens, but are slow to adopt and exploit Web 2.0 technologies.

The usage of Facebook social network in the developed countries is depicted in Figure 2A. The chart indicates the average value of usage as well as the position of each country accordingly to that value. Among diverse user profiles on Facebook there is increasing number of government profiles.
Governments are following modern Web trends trying to keep up with target audience. In average, $60 \%$ of public authorities in one country have a public profile on Facebook network. Only two out of six analysed countries are above that value (Republic of Korea and United States) among which United States has the highest score $100 \%$, while others are below. The lowest value has Canada $-40 \%$.

The usage of Facebook social network in the countries of Balkan region (Figure 2B) is considerably less than in the developed countries. Average number of Facebook profiles per country is $11 \%$. Romania leads among Balkan countries, while B\&H Federation does not have Facebook profiles of public authorities. 


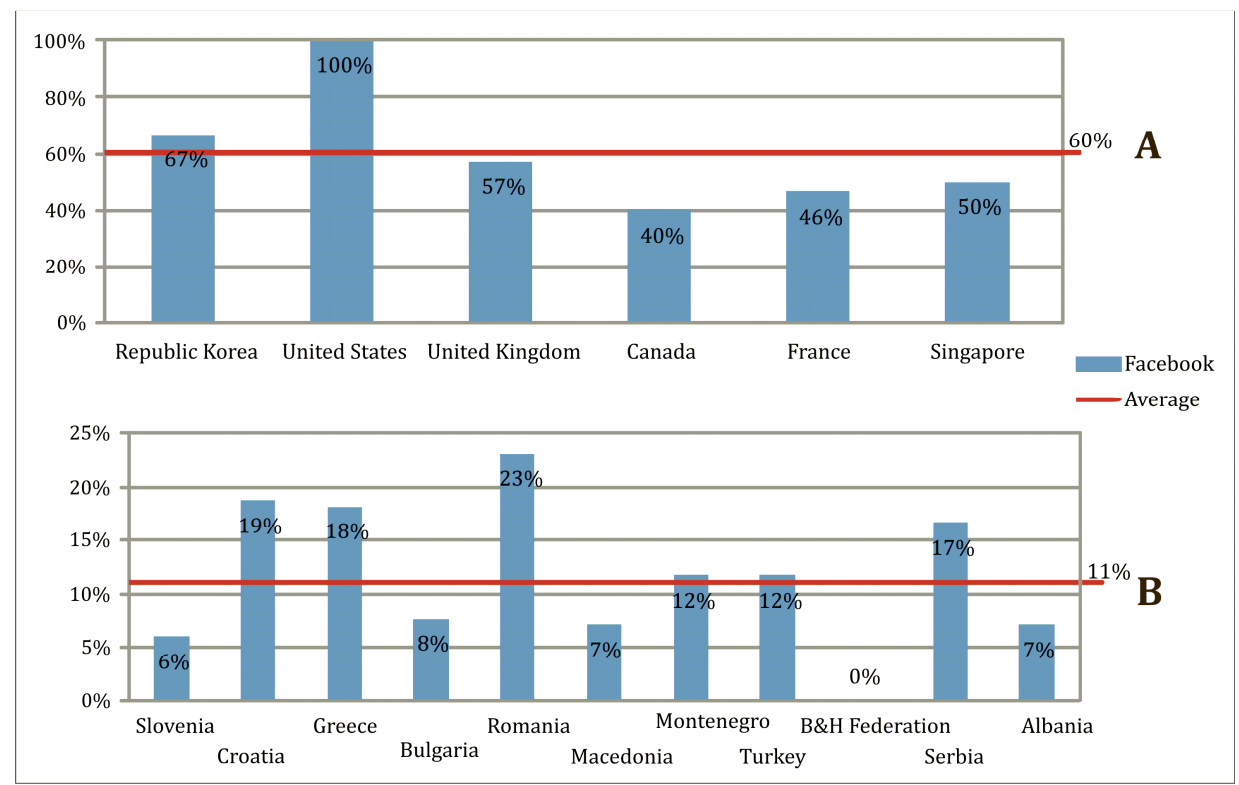

Fig2. The Usage of Facebook Social Network

When the results generated for developed and developing countries were compared it was clear that Balkan region is far behind more developed world countries. Figure 3 represents that comparison and visually illustrates the difference in the amount of Web 2.0 technology adoption. Total average usage of Web 2.0 tools in developed countries is $37 \%$ while in developing countries that number is three times smaller. The most used tool in both country groups is RSS with total of $81 \%$ usage in developed countries and $49 \%$ in developing countries. The least used tool in first country group is Scribd (3\%) and in Balkan group Wiki and Scribd (both $0 \%$ ).

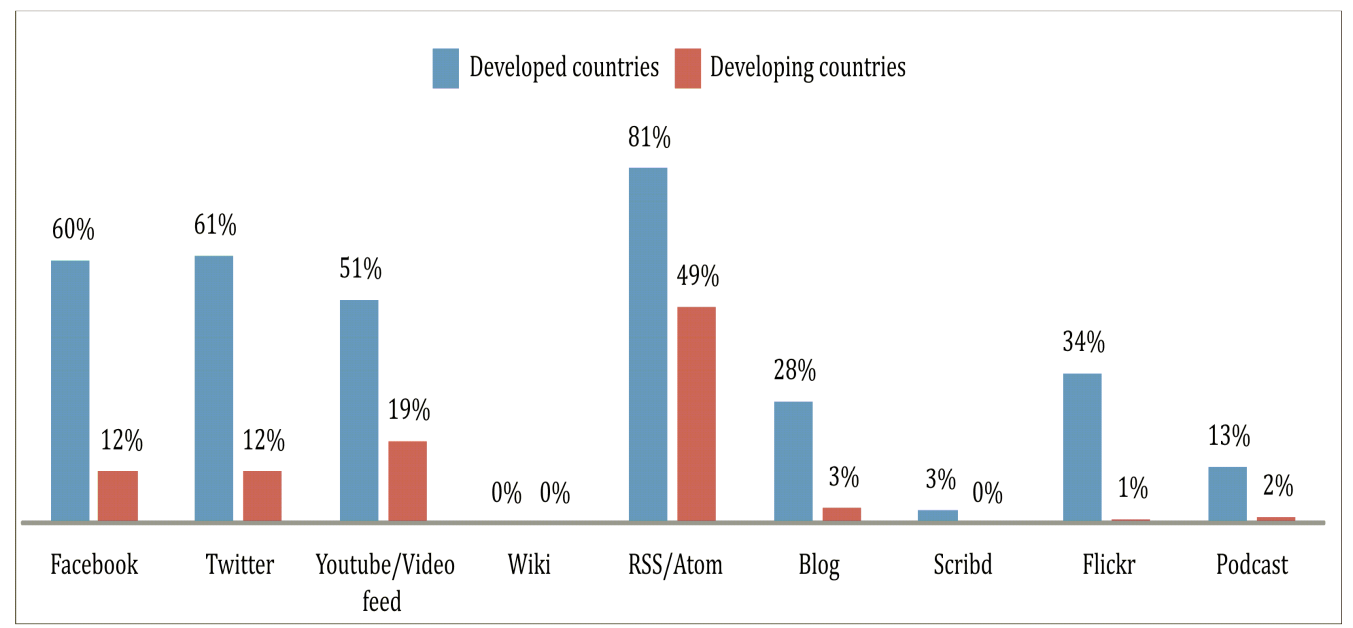

Fig3. Comparison of Web 2.0 Tools Usage in Developed and Developing Countries 


\section{Final Remarks and Conclusions}

Technology has drastically changed over the last few years and gained a major role in everyday life. Community's focus has been slowly transferred online where a new, virtual world has arisen. Web 2.0 set of technologies involves the public in creating this virtual world. Forums, blogs and online communities are just some of many Web 2.0 features where the user is the one that creates and modifies their content. Users shape the Web according to their needs, which is the most powerful feature of the new Web generation. In order to keep up with the public and reach their target audience, governments around the world also need to go online and offer new ways for getting information. Innovations in Web technologies have influenced the transition from e-government 1.0 to e-government 2.0 concept and many agree that suffix 2.0 in the new governmental concept name indicates the importance that Web 2.0 had in its creation.

E-government 2.0 implies virtual presence of the-government on popular social networks, as well as mandatory existence of thegovernment's Web portal, where thegovernment can share its data with the public, making it available, searchable and downloadable in various supported formats. Many governments around the world are successfully embracing this new concept. They have implemented data portals for publishing vast amounts of data, profiles on popular social networks for publishing news, opening discussions on hot topics and generally interacting with public users. But there are still numerous governments that are struggling with this new concept. Governments of the Balkan region are just some of them.

Although Web 2.0 tools are much more accepted and exploited in developed countries there is certain similarity with developing countries in the preferred Web 2.0 tools. The ways in which government public authorities use Web 2.0 tools varies significantly from government to government but most commonly these tools are used for publishing news and announcements relevant to their constituents. For this purpose Facebook, RSS, Twitter and YouTube are the most convenient Web 2.0 tools. This explains why both developed and developing countries prefer these tools over Wiki, Scribd and Podcast. This leads to another conclusion that government PAs' websites focus mostly on using Web 2.0 tools for displaying informative content in text (rarely video and audio) format, rather on applications that allow direct communication between government and its constituents (Wiki, Blog).

On the basis of presented results of Web 2.0 tools utilization among developed and developing countries on the Balkans, the obvious conclusion is that the Balkan region countries have a lot to accomplish in order to catch up with already highly developed world countries. For this matter we can propose six basic steps that could guidegovernments in the developing countries through the process of transformation towards e-government 2.0. Our goal is not to establish a strict and final procedure, but rather to give recommendations and help those who are confused by the vast number of new terms, technologies and concepts.

\section{Step 1: Strategy and Policy}

The first step in embracing e-government 2.0 concept should be developing a strategy for data publishing and enacting suitable data policies. As publicly available-governmental data is a key feature of e-government 2.0, it is very important to ensure that government information is available to citizens in a consistent, complete and easily discoverable form via online services. Create appropriate strategies, as for example strategy for publishing, managing and establishing data categories for easier organisation and data filtering. This further implies the need for creating a unique data catalogue, which would hold all published data in an organized manner in one place, thus enabling 
centralized approach towards data archiving. The entire process should be followed by enacting legislative framework that would define rules for data publishing, data standards, procedures for requesting data, but also restrict the ability to share nonpersonal data with employees, partners and citizens. Laws and strategy are equally important in e-government 2.0 introduction process. However, developing strategy and enacting laws is a very time consuming process that requires great effort and deep planning. This step, therefore, should be well thought out and pursued in a highly organized manner. The question is whether this step should ever be declared finished or whether it should be constantly revised.

\section{Step 2: Coming Online}

New technologies have transferred the public focus to virtual communities, transferring the audience online. In order to stay in touch with target audience, it is necessary for a government to follow this modern routine and join the mainstream online communities where it can reach citizens and gain their attention. Creating a Web profile does not seem like a demanding task, especially bearing in mind that most of Web 2.0 applications are free of charge and easy to use. However, there are many different online communities and applications, so the question here is where to begin. Probably the best solution would include creating several different Web profiles:

- Create a Facebook page for publishing relevant notifications, enabling citizens to see them and discuss governmental actions.

- Create a Twitter handle for publishing news of government events.

- Create YouTube channel for publishing videos about important events.

- Join an existing community for exchanging experiences and ideas with other governments, such as GovLoop.
- Allow audio and news feeds through RSS

There are truly a lot of options for becoming part of a virtual community. Careful planning and research are the best ways for choosing suitable social networks and online communities for a government.

\section{Step 3: E-government 2.0 Platform}

Creating e-government 2.0 platform implies creating an online platform that will enable the publishing of governmental data accordingly to adopted data policies and will make all government's services available for public use. E-government 2.0 platform is a complex system that comprises of several components which include all government Web profiles created on social networks, as well as the official government Web site that should act as a central component for data publishing. The most important concern is to develop suitable data platform that will enable publishing of all relevant governmental information. This can be done using one of the existing open data publishing platforms or by building a new one from scratch. The first option is preferable. There are many commercial and non-commercial open data platforms available on the Internet. In the case of noncommercial data platforms, IT responsible has to download the solution, install it on the-government Web portal and enter the data. In this case, the-government IT sector is responsible for the maintenance. In the case of a commercial solution, maintenance is included in the price and updates are in most cases free of charge. The second option is building data platform from beginning. If time and money are of the essence, the solution can be ordered from the IT Company; otherwise employees in thegovernment IT sector can do this on their own. Either way this is a time consuming option, and requires a lot of effort and a large team of IT professionals. It is up to thegovernment to decide what option is more preferable and doable. 


\section{Step 4: User Participation}

The fourth step is about user participation in the form of user feedback. User feedback is very important factor of e-government progress and one of the key e-government 2.0 features. It implies involving users in decision making processes and taking users' opinion into consideration. Getting user feedback can be done by enabling commenting published data on government's Web portal, participating in discussions on popular subjects with government representatives, filling online polls, grading contents etc. Even more important than getting users' feedback is accepting it and making relevant changes in accordance with it. In this way comprehensiveness and quality of published data can be significantly improved.

\section{Step 5: Collaboration}

Collaboration with agencies, other governments and users is of crucial importance for e-government 2.0. Through collaboration governments improve their infrastructure and processes as well as quality of data and services. Data published on the-government portal is coming from different sources. These sources are usually different agencies that are involved in researches in different areas. Thegovernment collaborates with these agencies by requesting and publishing their results of performed researches, thus offering them to public. Government should also collaborate with other governments in order to exchange experiences, learn some new techniques and apply new technologies and processes. Such collaborations could be pursued via government social networks such as GovLoop, seminars, conferences, workshops etc, which could be organized online. Collaboration with users is pretty much explained in Step 4 and it implies requesting and accepting users' feedback on governmental hot topics. Collaboration is a never-ending process, which requires full attention of the-government responsible.

\section{Step 6: Manage and Maintain}

The most important part of the process of embracing e-government 2.0 concept is contained in this final step: manage and maintain everything that has been implemented so far in order to ensure constant improvement of government's online existence. It involves data management, government Web portal, government online profiles, communication with citizens, agencies and other governments, etc. This is a large number of responsibilities and it requires forming a special team of experts that will exclusively deal with managing. The scope of responsibilities and priorities of the management team should be well defined, as well as individual roles and responsibilities of each team member. Responsibilities should be synchronized with the overall government strategy and enacted laws.

The steps we have proposed are meant to be the guidelines for introducing e-government 2.0 concept in governments and an incentive for transition from e-government 1.0 to a higher governmental level. This set of steps is neither strict nor final and every government is welcome to propose modifications as well as new steps that they find necessary in this process. We strongly believe this could help developing countries to start embracing the new concepts or at least better understand the goals behind e-government 2.0.

\section{References}

Anderson, P. (2007). "What is Web 2.0? Ideas, Technologies and Implications for Education," JISC Technology and Standards Watch, 7-12.

Archmann, S. \& Castillo Iglesias, J. (2010). "eGovernment: A Driving Force for Innovation and Efficiency in Public Administration,": EIPASCOPE 2010/1, 30-31, http://www.eipa.eu/.

Baumgarten, J. \& Chui, M. (2009). "eGovernment 2.0," McKinsey on Government, (4), 26-31. 
CIO/OFT (The New York State Chief Information Officer/Office for Technology), (2010). "The Status of E-Government and Social Networking in the Empire State," [Online], [Retrieved August 28, 2011], http://cio.ny.gov/assets/documents/EGovRe port.pdf

Chao, J. (2007). "Student Project Collaboration Using Wikis," Proceedings from CSEE\&T 2007: The 20th Conference on Software Engineering Education and Training, Dublin, Ireland.

Collins, S. (2009). Government 2.0, eGovernment and Culture, 'State of the eUnion: Government 2.0 and Onwards,' Gotze, J. \& Pedersen, C.B. (ed), 21gov.net

Crook, C., Fisher, T., Graber, R., Harrison, C., Lewin, C., Logan, C., Luckin, R., Oliver, M. \& Sharples, M. (2008)."Web 2.0 Technologies for Learning: The Current Landscape Opportunities, Challenges and Tensions," BECTA Research Report, [Online], [Retrieved August 28, 2011]. http://dera.ioe.ac.uk/1474/1/becta_2008_w eb2_currentlandscape_litrev.pdf

De Kool, D. \& Van Wamelen, J. (2008). "Web 2.0: A New Basis for E-Government?," Proceedings from ICTTA '08: Third International Conference on Information and Communication Technologies: From Theory to Applications, Damascus, Syria.

Di Maio, A. (2009). "Government 2.0: Gartner Definition," Industry Research, [Online], [Retrieved August 15, 2011], http://dc.gov/DC/OCTO/Publication\%20File s/government2_0_Gartner_Definition_G0017 2423.pdf

Dwivedi, Y. K., Williams, M. D., Mitra, A., Niranjan, S. \& Weerakkody, V. (2011). "Understanding Advances in Web Technologies: from Web 2.0 to Web 3.0," Proceedings from ECIS 2011: European Conference on Information Systems, Helsinki, Finland.
Eggers, W. D. (2005). Government 2.0: Using Technology to Improve Education, Cut Red Tape, Reduce Gridlock, and Enhance Democracy, Lanham MD, U.S.A.: Rowman \& Littlefield Publishers.

Eurostat,

(2011).

http://epp.eurostat.ec.europa.eu

Facebook, (2011). Statistics, [Online], [Retrieved September 01, 2011], http://www.facebook.com/press/info.php?s tatistics

Ferro, E. \& Molinari, F. (2009). "Framing Web 2.0 in the Process of Public Sector Innovation: Going Down the Participation Ladder," European Journal of ePractice, 9(1), 20-34.

García-Zubia, J., Irurzun, J., Angulo, I., Orduna, P., Ruiz-de-Garibay, J., Hernandez, U. \& Castro, M. (2010). "Developing a Second-Lifebased Remote Lab over the WebLab-Deusto Architecture," Proceedings from the REV2010, Stockholm, Sweden.

Geoghengan, M. W. \& Klass, D. (2005). 'Podcast Solutions: The Complete Guide to Podcasting,' Friends of ED.

Government 2.0 taskforce. (2009). "Engage : Getting on with Government 2.0," [Online], [Retrieved September 01, 2011], gov2.net.au/about/draftreport/

Government Computer News. (2010). "Strategic Report: Web 3.0 Tools," [Online], [Retrieved September 01, 2011], http://gcn.com/Web3Tools

Ho, A. T.- K. (2002). "Reinventing Local Governments and the E-Government Initiative," Public Administration Review, 62(4), 434-444.

Kaplan, A. M. \& Haenlein, M. (2010). "Users of the World, Unite! The Challenges and Opportunities of Social Media," Business Horizons, 53 (1), 59-68. 
Kaplan, A. M. \& Haenlein, M. (2011). "The Early Bird Catches the News: Nine Things You Should Know about Micro-blogging," Business Horizons, 54, 105-113.

Markoff, J. (2006). "Entrepreneurs See a Web Guided by Common Sense," [Online], [Retrieved September 15, 2011], http://www.nytimes.com/2006/11/12/busi ness/12web.html?pagewanted=all

Meier, A. \& Jakob-Brand, S. (2007). "Wikis, Weblogs, Podcasts and E-Government," Seminar thesis, University of Fribourg, [Online], [Retrieved 28 August, 2011], http://diuf.unifr.ch/main/is/sites/diuf.unifr. ch.main.is/files/file/studentprojects/reports /eGov_HS07_Weblogs_and_Wikis_

(AnjaMeier_StefanJakob).pdf

Millard, J. (2010). "e-Government 1.5: Is the Bottle Half Full or Half Empty?," European Journal of e-Practice, (9), 35-48.

Murugesan, S. (2007). "Understanding Web 2.0,'"IT Professional,' 9(4), 34-41.

Osimo, D. (2008). "Web 2.0 in Government. Why and How?," JRC Scientific and Technical Report, [Online], [Retrieved December 15, 2011],

http://ftp.jrc.es/EURdoc/JRC45269.pdf

Pascu, C. (2008). "An Empirical Analysis of the Creation, Use and Adoption of Social Computing Applications," JRC Scientific and Technical Report, [Online], [Retrieved December 15, 2011], http://ftp.jrc.es/EURdoc/JRC46431.pdf

Prensky, M. (2001). "Digital Natives, Digital Immigrants Part1," On the Horizon, 9(5).

Queensland State Archives. (2010). 'Recordkeeping and Web 2.0 Survey Report', [Online], [Retrieved August 20, 2011], http://www.archives.qld.gov.au/downloads/ recordkeeping_web_survey_report.pdf

Silcock, R. (2001). 'What is E-government?', Parliamentary Affairs, 54(1), 88-101.
Spivack, N. (2006). "Web 3.0: The Third Generation Web is Coming," [Online], [Retrieved March 01, 2012], http://lifeboat.com/ex/web.3.0

Tapscott, D. (1998). Growing Up Digital: The Rise of the Net Generation, New York: McGraw-Hill Companies.

Tapscott, D., Williams, A. \& Herman, D. (2008). 'Government 2.0: Transforming Government and Governance for the Twentyfirst Century,' Genera Corporation.

Timm, D. M. \& Duven, C. J. (2008). "Privacy and social networking sites," New Directions for Student Services, 124, 89 - 101.

Twitter. (2011). Statistics [Online], [Retrieved September 01, 2011], http://blog.twitter.com/2011/03/numbers.h tml

UNPAN. (2010). "United Nations EGovernment Survey: Leveraging Egovernment at a Time of Financial and Economic Crisis," [Online], [Retrieved August 20 , 2011], http://www2.unpan.org/egovkb/documents /2010/E_Gov_2010_Complete.pdf

Wauters, P. \& Lorincz, B. (2008). "User Satisfaction and Administrative Simplification within the Perspective of eGovernment Impact: Two Faces of the Same Coin?," European Journal of ePractice, 4, 1-10.

Wikipedia. (2011). "About Wikipedia," [Online], [Retrieved September 01, 2011], http://en.wikipedia.org/wiki/Wikipedia:Abo ut

YouTube. (2011). Statistics [Online], [Retrieved September 01, 2011], http://www.youtube.com/t/press_statistics

Zappen, J. P., Harrison, T. M. \& Watson, D. (2008). "A New Paradigm for Designing Egovernment: Web 2.0 and Experience Design," Proceedings of the 2008 international conference on digital government research, Montreal, Canada. 